\title{
GENETICAL STUDIES IN PEARS
}

\section{VEGETATIVE AND FRUIT CHARACTERS}

M. B. CRANE and D. LEWIS

John Innes Horticultural Institution, Bayfordbury, Hertford, Herts

Received 3.iii. $4^{8}$

GeNETIC studies on cultivated pears have been in progress at Merton since 193I. What concerned sterility and incompatibility has been previously reported upon (Crane and Lewis, 1942; Lewis and Modlibowska, 1942). The present account deals with the inheritance of characters of the leaves, shoots, and fruit. With seedling pears the length of time from seed to maturity varies greatly even within the same family, and many seedlings have not yet borne fruits; hence the data on fruit characters are less complete than those on the vegetative characters. Fifteen diploid varieties have been used as parents. These varieties and their known genetic constitutions are given in table $\mathbf{I}$.

TABLE I

Genetic constitutions of varieties

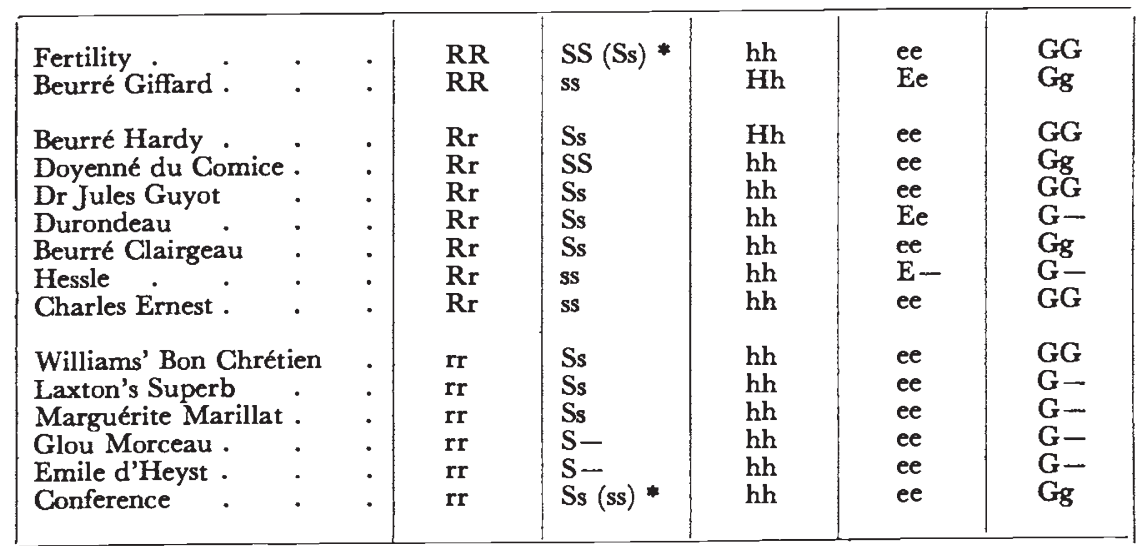

$\mathrm{R}=$ summer shoots red

$\mathrm{S}=$ leaf margin serrate or crenate

$\mathbf{r}=$ summer shoots green or pale yellowish-green

$H=$ summer shoots hairy

$\mathrm{E}=$ main leaf midrib eglandular

$\mathrm{G}=$ leaves green or dark green

$\mathrm{s}=$ leaf margin entire

$\mathrm{h}=$ summer shoots glabrous or sparsely hairy

$\mathrm{e}=$ main leaf midrib glandular

$\mathrm{g}=$ leaves pale green

* Somatic mutations

\section{VEGETATIVE CHARACTER DIFFERENCES}

Shont-colour : R-r.-The young, current season's shoots of pears fall into two main colour groups : red and green. In the red group the intensity of the pigmentation varies from a mere tinge to a dark 
red or purple colour almost completely covering the young shoot. In all individuals with coloured growth, the colour is influenced by environment. Thus shoots in the central part of a tree are not, as a rule, so deeply coloured as those more exposed. Differences also occur in the colour of the petioles and midribs of the leaves. The colour of the shoot is most clearly seen during the early weeks of growth. Later, colour differences are less distinct owing to the formation of bark, though it is often possible to distinguish green from red coloured individuals even on one-year-old wood, i.e. the previous season's growth.

Shoot-hairiness : $\mathrm{H}-\mathrm{h}$.- The young shoots of pears differ in their degrees of hairiness : (I) hairy, (2) very few hairs or glabrous. The surface of the young shoots, and also that of the young unfolding leaves, in the hairy class (I) are thickly covered with greyish hairs, and varieties in this class are readily distinguished from those with few hairs in class (2). Differences in hairiness are more readily observed in the early stages of growth. Later as the shoots become suberised, the hairy character becomes obscure.

Leaf-margin: $\mathrm{S}-\mathrm{s}$.-The leaves of pears can again be divided into two primary classes, those with a toothed and those with an entire, non-toothed, margin. On the lateral and terminal shoots of the current season's growth the margin of the leaf is often variable, but on the spur leaves the character of the leaf-margin is constant. Within the toothed class the margin varies from sharply serrate to almost crenate, but there is a continuous gradation and, so far, it has not been found possible to subdivide them with confidence.

Leaf-colour : G-g.-The leaves are dark or pale green. Variation occurs within the dark green class, some being darker green than others, but the pale green are always distinct.

Leaf-glands : $\mathrm{E}-\mathrm{e}$.-The midrib of the leaf is either free from glands or it is covered with small glands throughout its length. In the early stages of growth they are red, later they turn black. For convenience we have called these two types eglandular and glandular but the eglandular class have a few glands at the base of the leaf. The difference is constant even under diverse conditions and can be readily observed throughout the growing season.

Amongst the glandular varieties used as parents there is great variation in the number of glands along the midrib. Thus Dr Jules Guyot has an average of 179.3 ; Williams' Bon Chrétien II2.8; Conference 52.5 ; and Doyenné du Comice 29.4 per leaf.

As shown in table 2 the $F_{1}$ progeny has a mean gland number which is always lower than the arithmetic mean of the parents. Most $\mathrm{F}_{1}$ individuals have fewer glands than either parent. Only in one $\mathrm{F}_{1}$ family do seedlings occur with more glands than either of the parents; this is in the family raised from Conference $(52.5) \times$ Fertility $\left(89^{\circ} 0\right)$. These varieties are rather similar, or at least they 
are not so divergent in gland number as are the parents of the other $\mathrm{F}_{1}$ families.

TABLE 2

Inheritance of gland numbers

\begin{tabular}{|c|c|c|c|c|}
\hline \multirow{2}{*}{ Parents } & \multirow{2}{*}{$\begin{array}{l}\text { Parental gland } \\
\text { numbers }\end{array}$} & \multicolumn{2}{|c|}{ Mean of parents } & \multirow{2}{*}{ Mean of $F_{1}$} \\
\hline & & Arithmetic & Geometric & \\
\hline $\begin{array}{l}\text { Guyot } \quad \times \text { Giffard } . \\
\text { Guyot } \quad \times \text { Conference } \\
\text { Fertility } \times \text { Giffard } . \\
\text { Conference } \times \text { Fertillity } .\end{array}$ & $\begin{array}{r}179.3 \times 6.0 \\
179.3 \times 52.5 \\
89.0 \times 6.0 \\
52.5 \times 89.0\end{array}$ & $\begin{array}{r}92 \cdot 6 \\
115 \cdot 9 \\
47 \cdot 5 \\
70 \cdot 7\end{array}$ & $\begin{array}{l}32 \cdot 8 \\
99 \cdot 4 \\
23 \cdot 1 \\
68 \cdot 3\end{array}$ & $\begin{array}{l}25 \cdot 6 \\
89 \cdot 7 \\
23 \cdot 2 \\
67 \cdot 9\end{array}$ \\
\hline
\end{tabular}

Most varieties as table I shows are heterozygous in one or more respects. The variety Fertility is the only one homozygous for all five genes, being dominant for three and recessive for two. No varieties have been found to be homozygous hairy $\mathrm{HH}$, or homozygous eglandular EE. Nor has any recessive gg variety been found ; it is probable that they do not occur among cultivated varieties owing to a general lack of vigour being associated with the recessive pale green leaf character.

All the characters so far described have discontinuity with more or less continuous variation on one side, in four cases on the dominant and in one on the recessive side. Thus although they have given mendelian results most of the characters have a polygenic background.

The results obtained from the breeding experiments are given in table 3 .

\section{INHERITANCE}

Mutation.-Two evidences not included in table 2 were found of differences arising within varieties by mutation :-

(i) Beurré Giffard ss $\times$ Fertility SS gave abnormal results in respect of the leaf-margin character. Forty-one Ss and I 5 ss were obtained when all Ss seedlings were expected. Similarly in a small reciprocal family of ro individuals, $9 \mathrm{Ss}$ and I ss seedlings were obtained. It seems that Fertility must be a mosaic : SS/Ss.

(ii) Several trees of the variety Conference have been used as parents. It was noticed that they differed in their leaf-margins. The majority had an entire, but two had a slightly serrate, margin. Families raised from crossing these two slightly serrate trees with recessive ss varieties, gave approximately equality of serrate and entire. Thus these slightly serrate trees of Conference are heterozygous Ss for the leaf-margin character. Presumably these had given the entire ss by mutation. 


\section{FRUIT CHARACTER DIFFERENCES}

In contrast to the discontinuity of the characters of the leaves and shoots, the range of variation of the characters of the fruit is more or less continuous. Therefore, although care has been taken in recording and also in the classification of the seedlings in the families

TABLE 3

Families from pear crosses grouped according to the segregation types

\begin{tabular}{|c|c|c|c|c|c|c|}
\hline & \multicolumn{2}{|c|}{ No. of } & & \multicolumn{2}{|c|}{$\chi^{2 *}$} & \multirow[b]{2}{*}{$\begin{array}{l}\text { p Hetero- } \\
\text { geneity }\end{array}$} \\
\hline & families & varieties & & $\begin{array}{c}\text { Segrega- } \\
\text { tion }\end{array}$ & $\begin{array}{l}\text { Hetero- } \\
\text { geneity }\end{array}$ & \\
\hline Growth colour- & & & $\mathbf{R} \quad \mathbf{r}$ & & & \\
\hline $\begin{array}{l}\mathrm{RR} \times(\mathrm{RR} \text { or } \mathrm{Rr} \text { or } \mathrm{rr}) \\
\mathrm{Rr} \times \mathrm{Rr}\end{array}$ & 12 & 6 & $570: \quad 0$ & 0.0 & 0.0 & $\ldots$ \\
\hline $\begin{array}{l}\mathbf{R r} \times \mathbf{R r} \\
\mathbf{R r} \times \mathbf{r r} .\end{array}$ & $\begin{array}{r}0 \\
15\end{array}$ & $\begin{array}{l}5 \\
8\end{array}$ & $\begin{array}{r}95 \vdots 38 \\
148: \quad 156\end{array}$ & $\begin{array}{l}0.894 \\
0.210\end{array}$ & $\begin{array}{r}2.210 \\
10.625\end{array}$ & $\cdot 9$ \\
\hline rr $\times \mathbf{r r}$ & 5 & 4 & $0: 147$ & 0.0 & 0.0 & $\ldots$ \\
\hline $\begin{array}{l}\text { Growth hairiness- } \\
\mathrm{Hh} \times \mathrm{hh} . \\
\mathrm{hh} \times \mathrm{hh} .\end{array}$ & $\begin{array}{r}7 \\
45\end{array}$ & $\begin{array}{r}6 \\
10\end{array}$ & 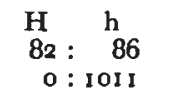 & $\begin{array}{l}0.095 \\
0.0\end{array}$ & $\begin{array}{c}22 \cdot 803 \\
0.0\end{array}$ & $\begin{array}{c}<\cdot O I \\
\ldots\end{array}$ \\
\hline $\begin{array}{l}\text { Leaf-margin- } \\
\mathrm{SS} \times(\mathrm{SS} \text { or } \mathrm{Ss} \text { or } \mathrm{ss}) \\
\mathrm{Ss} \times \mathrm{Ss} . \\
\mathrm{Ss} \times \mathrm{ss} .\end{array}$ & $\begin{array}{r}16 \\
12 \\
9\end{array}$ & $\begin{array}{l}8 \\
8 \\
7\end{array}$ & $\begin{array}{lr}s & s+ \\
537: & o \\
283: & 77 \\
127: & 72\end{array}$ & $\begin{array}{l}0 \cdot 0 \\
2 \cdot 059 \\
15 \cdot 201\end{array}$ & $\begin{array}{l}0 \cdot 0 \\
41 \cdot 519 \\
22 \cdot 54 \mathrm{I}\end{array}$ & $\begin{array}{l}\cdots \\
<\bullet \text { OI } \\
<\cdot 01\end{array}$ \\
\hline $\begin{array}{l}\text { Leaf-colour- } \\
\qquad \mathrm{Gg} \times \mathrm{Gg}\end{array}$ & 4 & 4 & $\begin{array}{ll}G & g \\
77: & 22\end{array}$ & 0.405 & 0.449 & $\cdot 9$ \\
\hline $\begin{array}{l}\text { Leaf-glands-- } \\
\text { Ee } \times \mathrm{Ee} \text {. } \\
\mathrm{Ee} \times \mathrm{ee} \\
\text { ee } \times \mathrm{ee} \text {. }\end{array}$ & $\begin{array}{r}2 \\
8 \\
37\end{array}$ & $\begin{array}{r}3 \\
8 \\
11\end{array}$ & $\begin{array}{rl}\mathrm{E} & \mathrm{e} \\
123: & 49 \\
82: & 124 \ddagger \\
0: & 899\end{array}$ & $\begin{array}{l}I \cdot 116 \\
8 \cdot 553 \\
0 \cdot 0\end{array}$ & $\begin{array}{l}x \cdot 697 \\
17 \cdot 268 \\
0 \cdot 0\end{array}$ & $\begin{array}{l}\cdot 2 \\
\cdot 02 \\
\cdots\end{array}$ \\
\hline
\end{tabular}

* $\chi^{2}$ for $\mathrm{I}$ degree of freedom when $\mathrm{p}=\cdot 05=3 \cdot 84 \mathrm{I}$

+ Deficiency of recessives

\#xcess of recessives

raised, it is not possible, at the present stage of the investigations, to attempt a detailed genetic analysis of fruit characters. Nevertheless differences in segregation can often be correlated with the characters of the parents, and although there is no complete dominance of any fruit character, incomplete dominance is commonly evident.

Size.-The size of the fruit of pears fluctuates as a result of differences in environment, nutrition and other causes. It is impossible to define such characters accurately, and our measurements and determinations must be read as average figures under our conditions. The parent varieties and seedlings, however, have been grown under similar conditions, consequently differences due to these causes are not likely to be considerable. Most of the seedlings dealt with in 
this paper have carried fruits for four or more seasons and their shape, size, time of maturity, etc., have been recorded and compared from year to year.

TABLE 4

Inheritance of fruit shape

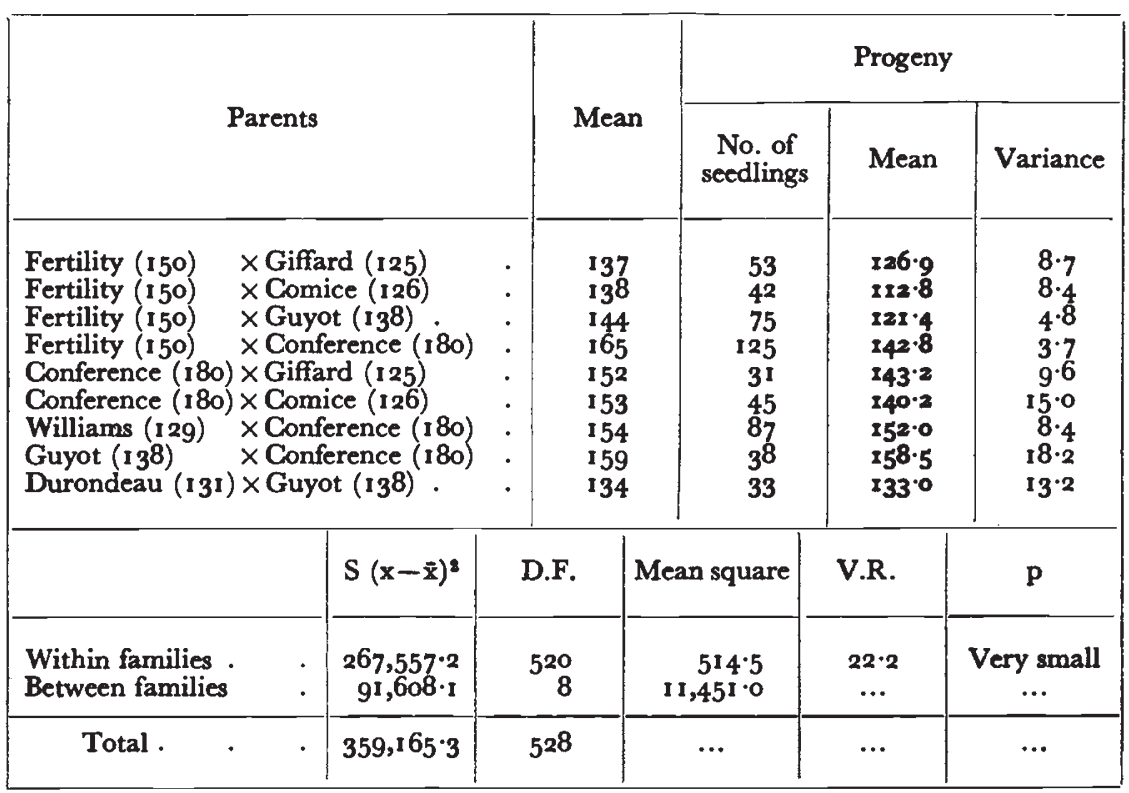

TABLE 5

Inheritance of fruit size

\begin{tabular}{|c|c|c|c|c|c|c|c|}
\hline & & & & & & Progen & \\
\hline & Parent & & & & $\begin{array}{l}\text { No. of } \\
\text { seedlings }\end{array}$ & Mean & Variance \\
\hline $\begin{array}{l}\text { Fertility (49) } \\
\text { Fertility }(49) \\
\text { Fertility }(49) \\
\text { Fertility (49) } \\
\text { Conference (168) } \\
\text { Conference (168) } \\
\text { Williams (228) } \\
\text { Guyot (198) } \\
\text { Durondeau (188) }\end{array}$ & $\begin{array}{l}\times \text { Giff } \\
\times \text { Com } \\
\times \text { Guy } \\
\times \text { Con } \\
\times \text { Giff } \\
\times \text { Com } \\
\times \text { Con } \\
\times \text { Con } \\
\times \text { Guy }\end{array}$ & $\begin{array}{l}\text { d }(72) \\
\text { ce }(147) \\
t(198) \\
\text { rence }(168) \\
\text { d ( }(72) . \\
\text { ce (147) } \\
\text { rence (168) } \\
\text { rence (168) } \\
\text { t (198). }\end{array}$ & & & $\begin{array}{r}53 \\
42 \\
75 \\
125 \\
31 \\
45 \\
87 \\
38 \\
33\end{array}$ & $\begin{array}{l}57 \cdot 0 \\
64 \cdot 4 \\
83 \cdot 9 \\
63 \cdot 4 \\
57 \cdot 7 \\
74 \cdot 9 \\
73 \cdot 7 \\
89 \cdot 1 \\
75 \cdot 9\end{array}$ & $\begin{array}{r}24 \cdot 0 \\
16 \cdot 0 \\
3 \cdot 5 \\
4 \cdot 1 \\
13 \cdot 9 \\
30 \cdot 3 \\
7 \cdot 9 \\
29 \cdot 5 \\
13.6\end{array}$ \\
\hline & & $S(x-\bar{x})^{2}$ & D.F. & & ean square & V.R. & p \\
\hline $\begin{array}{l}\text { Within families } \\
\text { Between families }\end{array}$ & & $\begin{array}{r}462,74^{\circ} \cdot 7^{\circ} \\
52,862 \cdot 87\end{array}$ & $\begin{array}{r}520 \\
8\end{array}$ & & $\begin{array}{r}889 \cdot 886 \\
, 607 \cdot 859\end{array}$ & $\begin{array}{c}7 \cdot 425 \\
\ldots\end{array}$ & $\begin{array}{c}\text { Very small } \\
\ldots\end{array}$ \\
\hline Total. & & $5^{15} 5,603.57$ & 528 & & $\ldots$ & $\ldots$ & ... \\
\hline
\end{tabular}


TABLE 6

Inheritance of fruit length

\begin{tabular}{|c|c|c|c|c|c|c|c|}
\hline \multirow{2}{*}{\multicolumn{3}{|c|}{ Parents }} & \multirow{2}{*}{\multicolumn{2}{|c|}{ Mean }} & \multicolumn{3}{|c|}{ Progeny } \\
\hline & & & & & $\begin{array}{l}\text { No. of } \\
\text { seedlings }\end{array}$ & Mean & Variance \\
\hline \multicolumn{3}{|c|}{$\begin{array}{ll}\text { Fertility }(7 \cdot 5) & \times \text { Giffard }(7 \cdot 5) \\
\text { Fertility }(7 \cdot 5) & \times \text { Comice }(9 \cdot 7) \\
\text { Fertility }(7 \cdot 5) & \times \text { Guyot }(\mathrm{I} \cdot 5) \\
\text { Fertility }(7 \cdot 5) & \times \text { Conference }(\mathrm{I} \cdot \mathrm{I} \cdot 0) \\
\text { Conference }(\mathrm{I} \cdot 3 \cdot 0) \times \text { Giffard }(7 \cdot 5) \\
\text { Conference }(\mathrm{I} \cdot 0) \times \text { Comice }(9 \cdot 7) \\
\text { Williams }(\mathrm{I} \mathrm{I} \cdot 5) \times \text { Conference }(\mathrm{I} \cdot 0) \\
\text { Guyot }(\mathrm{I} \cdot 5) & \times \text { Conference }(\mathrm{I} \cdot 0) \\
\text { Durondeau }(\mathrm{I} \cdot 5) \times \text { Guyot }(\mathrm{I} \cdot 5 \cdot 5)\end{array}$} & \multicolumn{2}{|c|}{$\begin{array}{l}7 \cdot 5 \\
8 \cdot 6 \\
9 \cdot 5 \\
10 \cdot 2 \\
10 \cdot 2 \\
11 \cdot 3 \\
12 \cdot 2 \\
12 \cdot 2 \\
11 \cdot 5\end{array}$} & $\begin{array}{r}53 \\
42 \\
75 \\
125 \\
31 \\
45 \\
87 \\
38 \\
33\end{array}$ & $\begin{array}{l}6 \cdot 9 \\
6 \cdot 8 \\
7 \cdot 7 \\
7 \cdot 9 \\
7 \cdot 7 \\
8 \cdot 7 \\
8 \cdot 7 \\
9 \cdot 5 \\
8 \cdot 0\end{array}$ & $\begin{array}{l}.056 \\
.049 \\
.028 \\
.013 \\
.043 \\
.063 \\
.030 \\
.087 \\
.043\end{array}$ \\
\hline & & $S(x-\bar{x})^{2}$ & D.F. & & an square & V.R. & $\mathrm{p}$ \\
\hline $\begin{array}{l}\text { Within families } \\
\text { Between families }\end{array}$ & & $\begin{array}{r}\mathrm{I}, \mathrm{I} 5 \mathrm{x} \cdot 079 \\
\mathbf{2 6 5} \cdot 6 \mathbf{2 9}\end{array}$ & $\begin{array}{r}520 \\
8\end{array}$ & & $\begin{array}{r}2 \cdot 213 \\
33 \cdot 204\end{array}$ & $\underset{14 \cdot 99}{\ldots}$ & $\begin{array}{c}\text { Very small } \\
\ldots\end{array}$ \\
\hline Total . & & $\mathrm{I}, 4 \mathrm{I} 6 \cdot 708$ & $5^{28}$ & & $\ldots$ & $\ldots$ & $\cdots$ \\
\hline
\end{tabular}

The whole of the data with respect to size and also shape of fruit is not given in this paper, but the hereditary behaviour shown in text figures $1-3$ and tables $4^{-6}$ is typical of the other families raised.

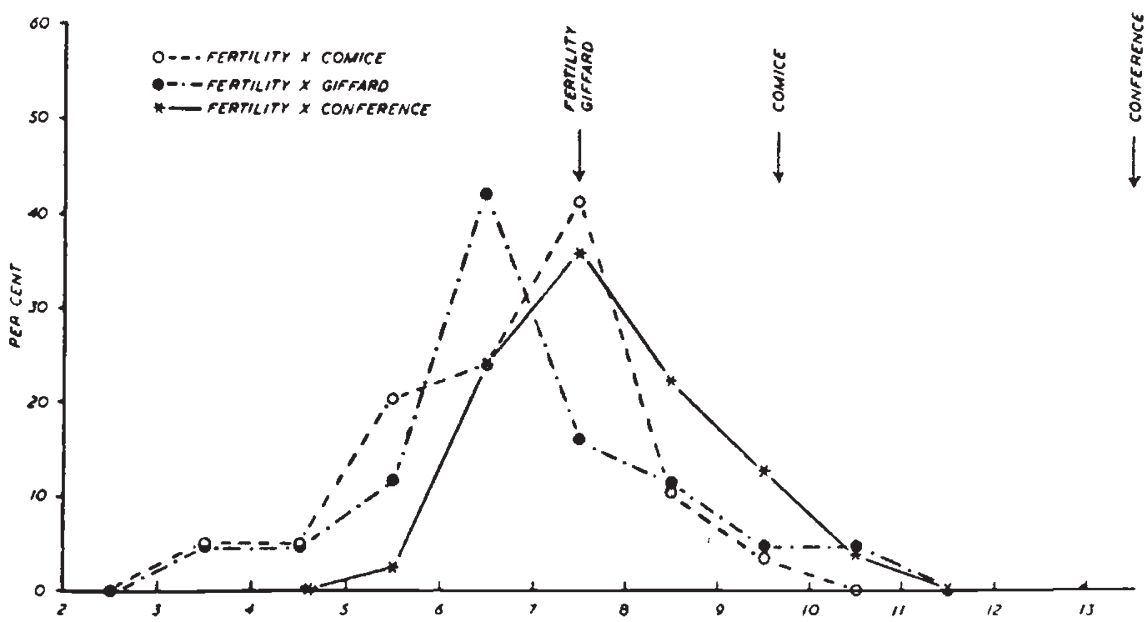

Fig. 1.-Range of variation of fruit length in the progenies from crossing pear varieties.

The mean size of the parents and of the progeny of nine families is given in table 4. The figures denoting fruit size were derived from the formula, length $\times(\text { radius })^{2}$, this although not allowing for differences 
in shape gives an approximate measure of relative size. In all families we have raised, the mean size of the fruit of the progeny is smaller than the mean size of the parents.

Shape.-The shape of the fruit also fluctuates subject to the environment, although less so than size. In some cases shape is

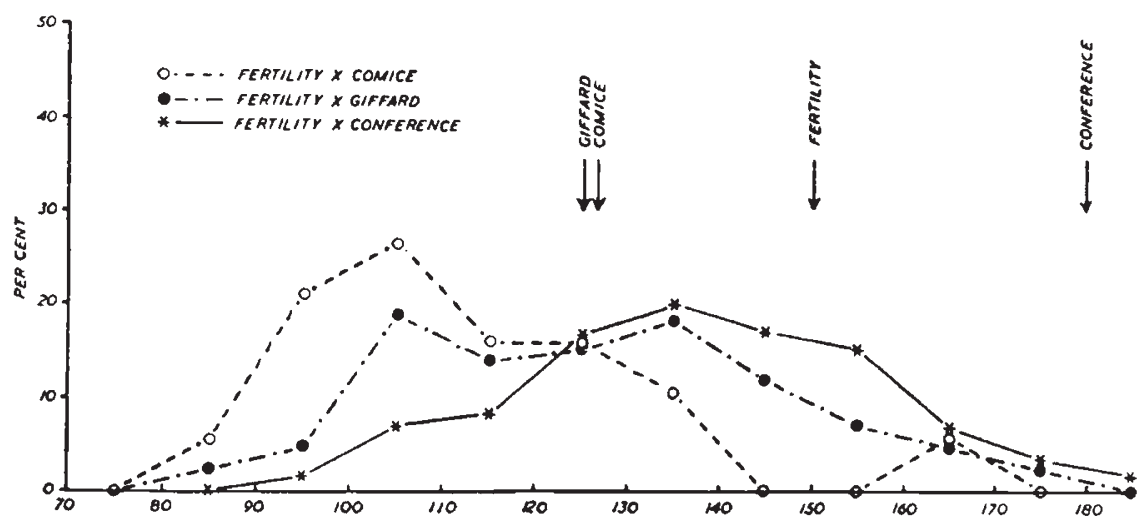

F10. 2.-Range of variation of fruit shape in the progenies from crossing pear varieties.

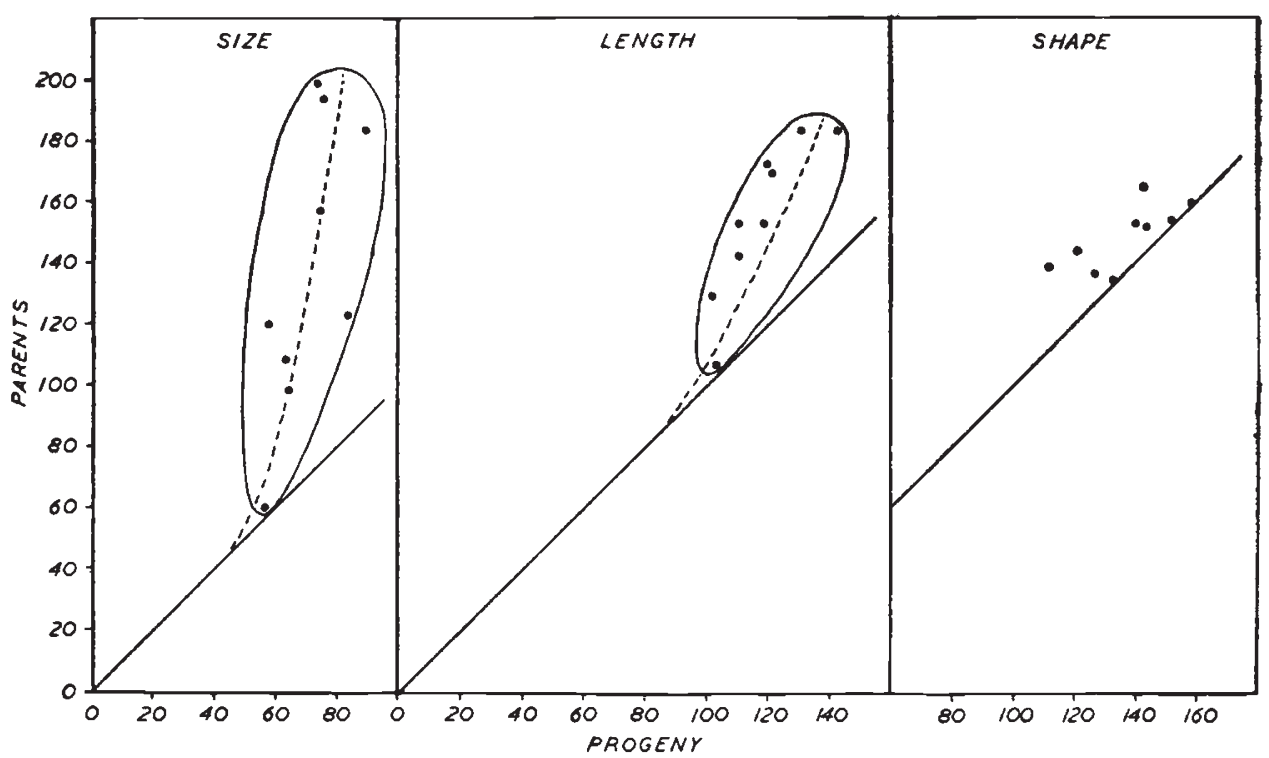

Fic. 3.-Graphs showing the relationship of fruit size, length and shape in parents and progeny:from data in tables 4,5 and 6 .

correlated with the number of seeds formed within the fruit. Fruits with few or no seeds are generally more elongated than those with many. The mean shape and mean length of the parents and of the progeny of nine families are given in tables 5 and 6 , and the range of variation found in the progeny of three families in the length and shape of the fruits are given in figs. I-3. The figures for fruit shape 
represent the ratio length/breadth expressed as a percentage. At Ioo, the fruits are round, or at least their greatest breadth and length is the same. Above roo, fruits are long and, below roo, flat. The mean length of the progeny is in all cases lower than the mean of the parents, and hence as shown in fig. 2, a majority of the progeny are shorter and rounder than either parent.

Surface. - The surface of the fruits of pears can be covered with a heavy russet coat, or it can be free from russet and almost smooth. Between these extremes all degrees of russeting occur. In these experiments we have not used any heavily russet varieties as parents, but only part russets such as Conference, Fertility, Durondeau, Hardy, and Comice and relatively smooth varieties such as Guyot, Giffard, Williams, and Marillat. From crosses between these the results were as follows :-

partly russet $\times$ partly russet , , $\times$ smooth
I 66 partly russet, I I4 smooth

I87 " , 273 ,

This russet character is the most variable we have studied, and in particular in the partly russet kinds it appears to fluctuate widely according to environment.

Wellington (1913) reported that, in the European varieties of pears, Pyrus communis, the green (non-russet) skin is dominant to the russet brown skin, but our results suggest that the inheritance of russetness is more complicated. In the Japanese pear, Pyrus serotina Kikuchi (1930) states that the russet skin behaves as a dominant and that two genes $\mathrm{R}$ and $\mathrm{I}$ govern the russet character. $\mathrm{R}$ gives russet brown, $r$ smooth green, $R R$ gives constant russet when $R$ is heterozygous, I partially inhibits cork formation to which russetness is due, so that it does not extend over the whole surface of the fruit. The double heterozygotes $\mathrm{Rr}$ Ii fluctuate considerable, and under moist climatic conditions they are much more russet than under dry conditions.

TABLE 7

Season of ripening

\begin{tabular}{|c|c|c|c|c|c|c|c|}
\hline & & Aug. & Sept. & Oct. & Nov. & Dec. & Jan. \\
\hline Fertility (Oct.) & $\times$ Giffard (Aug.) & 29 & 18 & 14 & $\cdots$ & $\cdots$ & $\cdots$ \\
\hline Fertility (Oct.) & $\times$ Guyot (Sept.) & II & 44 & 10 & $\ldots$ & $\ldots$ & $\ldots$ \\
\hline Fertility (Oct.) & $\times$ Conference (Oct.-Nov.) & 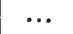 & 40 & $3^{8}$ & 1 & ... & $\ldots$ \\
\hline Fertility (Oct.) & $\times$ Comice (Nov.) & I & 10 & 13 & 1 & $\ldots$ & $\ldots$ \\
\hline Conference (Óct.-Nov.) & $\times$ Guyot (Sept.) & 6 & 14 & 4 & & $\ldots$ & $\ldots$ \\
\hline Conference (Oct.-Nov.) & $\times$ Marillat (Sept.) & 10 & 25 & 15 & 2 & $\ldots$ & $\mathbf{I}$ \\
\hline Conference (Oct.-Nov.) & $\times$ Williams (Sept.) & 7 & 42 & 18 & 5 & $\ldots$ & $\mathbf{I}$ \\
\hline Conference (Oct.-Nov.) & × Durondeau (Oct.-Nov.) & $\ldots$ & 14 & 7 & 4 & $\ldots$ & I \\
\hline Conference (Oct.-Nov.) & $\times$ Comice (Nov.) & ... & 22 & 19 & I & $\ldots$ & $\cdots$ \\
\hline Comice (Nov.) & $\times$ Williams (Sept.) & $\ldots$ & 4 & Io & I & $\ldots$ & $\ldots$ \\
\hline Comice (Nuv.) & X Clairgeau (Nov.-Dec.) & $\ldots$ & 8 & 16 & $\cdots$ & $\ldots$ & 2 \\
\hline Durondeau (Óct.-Nov.) & X Guyot (Sept.) & 3 & $2 \mathrm{I}$ & 12 & I & $\ldots$ & $\ldots$ \\
\hline
\end{tabular}


Season of ripening.- The season of ripening of the fruit of the parent varieties and of a number of seedlings is given in table 7. The mean season of ripening of the seedlings is in all families much earlier than that of the parents and the proportion of seedlings which are later than the latest ripening parent is remarkably small.

\section{FRUIT FLAVOUR}

The flavour of the fruit of pears is particularly difficult to determine. In the early maturing seedlings it is often ephemeral and the time of picking and testing is of the first importance. Analysis of the flavour of the seedlings we have raised is far from complete but our preliminary classification is given in table 8 . The best flavoured seedlings occur in the aromatic and sub-acid classes.

TABLE 8

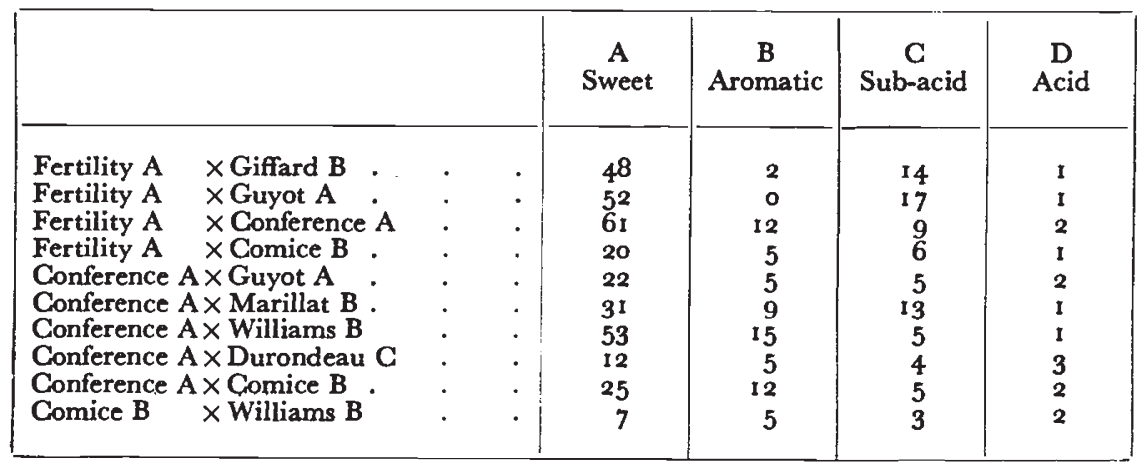

\section{DISEASE RESISTANCE}

For the past seven years we have been indebted to the Lord Wandsworth Agricultural College, Long Sutton, Hants, for growing a number of families of seedling pears which it was not possible to grow at Merton owing to lack of land. The trees were raised during the years 1936-39, and were planted at Long Sutton in February r 94 I.

Owing to war-time difficulties no spraying, nor pruning, nor manuring, nor other cultivation was carried out after 1943. In one way these conditions have added to the value of the experiments : the ravages of disease were unchecked. In particular, pear scab, Venturia pirina, which is probably the most troublesome disease of cultivated pears, was rampant throughout the plantation. This showed us the incidence of the disease in the different families and hence the genetic value of the parental varieties in regard to scab resistance. Amongst the seedlings there was great variation in the severity of the attack. In a few families, a small proportion of the seedlings were free from scab, and presumably immune from the disease. 
The seedlings were recorded and classified according to the severity of scab attack in classes as follows :-

I. Extremely severe ; 2. severe ; 3. moderate ; 4. slight ; 5. scab free.

TABLE 9

Parents of the families and numbers of seedlings in the classes of scab resistance

\begin{tabular}{|c|c|c|c|c|c|c|c|c|c|}
\hline & & & & lasses & & & & & \\
\hline A. Gipfard & $\times$ Conference & 2 & 6 & 9 & 7 & 6 & 30 & $20 \cdot 0$ & $3^{*}$ \\
\hline $\begin{array}{l}\text { B. GiFraRd } \\
\text { GifraRd }\end{array}$ & $\begin{array}{l}\times \text { Fertility } \\
\times \text { Durondeau }\end{array}$ & $\begin{array}{l}60 \\
26\end{array}$ & $\begin{array}{l}55 \\
4^{8}\end{array}$ & $\begin{array}{l}33 \\
6 \mathbf{x}\end{array}$ & $\begin{array}{l}22 \\
18\end{array}$ & $\begin{array}{l}8 \\
0\end{array}$ & $\begin{array}{l}\text { I } 78 \\
\text { I } 53\end{array}$ & $2 \cdot 4$ & $\begin{array}{l}4 \\
5\end{array}$ \\
\hline $\begin{array}{l}\text { C. Conperence } \\
\text { Conperence }\end{array}$ & $\begin{array}{l}\times \text { E. d'Heyst } \\
\times \text { Hardy }\end{array}$ & $\begin{array}{l}17 \\
23\end{array}$ & $\begin{array}{l}29 \\
39\end{array}$ & $\begin{array}{r}2 \\
25\end{array}$ & $\begin{array}{r}I \\
20\end{array}$ & $\begin{array}{l}0 \\
4\end{array}$ & $\begin{array}{r}49 \\
\text { I I I }\end{array}$ & $2 \cdot 5$ & $\mathrm{IO}^{*}$ \\
\hline $\begin{array}{l}\text { D. Hardy } \\
\text { Comice } \\
\text { Williams } \\
\text { Hessle }\end{array}$ & $\begin{array}{l}\times \text { CONFERENCE } \\
\times \text { CONPERENCE } \\
\times \text { CONPERENCE } \\
\times \text { CONPERENCE }\end{array}$ & $\begin{array}{r}42 \\
1 \\
0 \\
8\end{array}$ & $\begin{array}{r}10 \\
11 \\
2 \\
8\end{array}$ & \begin{tabular}{l|l}
9 \\
5 \\
5 \\
6
\end{tabular} & $\begin{array}{l}0 \\
6 \\
0 \\
0\end{array}$ & $\begin{array}{l}0 \\
2 \\
0 \\
0\end{array}$ & $\begin{array}{r}61 \\
25 \\
7 \\
22\end{array}$ & $1 \cdot 7$ & $\begin{array}{l}1 \\
3^{*} \\
4^{*} \\
0^{*}\end{array}$ \\
\hline $\begin{array}{l}\text { E. Comice } \\
\text { Durondeau } \\
\text { Fertility } \\
\text { Comice } \\
\text { Comice } \\
\text { Marillat } \\
\text { Hardy } \\
\text { Hardy }\end{array}$ & $\begin{array}{l}\times \text { Durondeau } \\
\times \text { Comice } \\
\times \text { Guyot } \\
\times \text { Glou Morceau } \\
\times \text { Williams } \\
\times \text { Durondeau } \\
\times \text { Comice } \\
\times \text { Glou Morceau }\end{array}$ & $\begin{array}{r}21 \\
25 \\
14 \\
9 \\
2 \\
0 \\
20 \\
24\end{array}$ & $\begin{array}{r}8 \\
6 \\
3 \\
39 \\
8 \\
8 \\
1 \\
49 \\
39\end{array}$ & \begin{tabular}{r|}
0 \\
2 \\
0 \\
16 \\
2 \\
3 \\
13 \\
13
\end{tabular} & $\begin{array}{l}\text { o } \\
0 \\
0 \\
0 \\
\text { I } \\
\text { I } \\
\text { o } \\
\text { o }\end{array}$ & $\begin{array}{l}0 \\
0 \\
0 \\
0 \\
0 \\
0 \\
0 \\
0\end{array}$ & $\begin{array}{l}29 \\
33 \\
\text { I } \\
44 \\
13 \\
5 \\
82 \\
76\end{array}$ & $0 \cdot 0$ & $\begin{array}{l}0 \\
8 * \\
0^{*} \\
0 \\
1^{*} \\
12 \\
2 \\
4\end{array}$ \\
\hline & & 294 & $34^{I}$ & 204 & 76 & 20 & 935 & $\ldots$ & $5^{8}$ \\
\hline
\end{tabular}

* Quince stock : other families, own roots

Fifty-eight trees died, 42 of these were in the families on Quince " $\mathrm{C}$ " rootstock, a mortality of $\mathrm{I} 18$ per cent. ; 16 were in families growing on their own roots, a mortality of only 2.5 per cent. It is, therefore, probable that the high mortality in the families on Quince " $\mathrm{G}$ " was mainly due to stock-scion incompatibility.

The proportion of seedlings within the different classes varied, but in 13 out of the 17 families more than $5^{\circ}$ per cent. were in the severely attacked first two classes. The 20 scab-free seedlings all occurred in families where either one or both parents were the varieties Conference or Beurré Giffard. But not all the families where one of these varieties was a parent gave resistant seedlings.

Conference, the most widely grown pear in this country, has long been recognised as being to some extent a scab resistant variety. Giffard is less grown and its degree of resistance to scab is not known.

The families in table 6 are arranged in five classes:- $\mathrm{A}$ are those between Giffard and Conference. B and C are those where Giffard 
or Conference was used as a female parent, $\mathrm{D}$ those where Conference was used as a male parent, and E those where neither Giffard and Conference were used.

The differences in proportion of scab-free seedlings between the five classes suggests that Giffard and Conference have a high resistancegiving capacity. At the same time the absence or low proportion of scab-free seedlings when Conference is used as male and particularly in the reciprocal cross with Hardy indicates that scab resistance depends partly on a cytoplasmically transmitted determinant. It remains to be discovered how permanent this determinant is.

Beurré Giffard has narrow, stiff and somewhat hairy leaves. The seedlings raised from Beurré Giffard $\times$ Fertility were classified for leaf shape as follows: (I) broad ; (2) moderately broad ; (3) moderately narrow ; (4) narrow.

There were 178 seedlings in this family and the number in these different classes were :-

\begin{tabular}{|cc|c|c|c|c|}
\hline Classes & & $(\mathrm{I})$ & $(2)$ & $(3)$ & $(4)$ \\
\hline Seedlings scab-infected &. & 7 & 60 & 103 & 8 \\
Seedlings scab-free & $\cdot$ & $\ldots$ & 1 & 3 & 4 \\
\hline
\end{tabular}

The distribution of the 8 scab-free seedlings in the family is shown in italics. The stiff narrow leaf, therefore, appears to be associated with resistance to scab.

\section{DISCUSSION}

The characters of the leaves and shoots of pears which we have studied have shown discontinuous variation. Dominance occurs and they show the expected segregation ratios for single factor differences. The characters of the fruit on the contrary have shown continuous variation. This probably results from the action of a number of genes whose expression in the phenotype is cumulative. The results with pear scab suggest that genetical resistance to scab is determined by a certain balance of genes having small but cumulative effects.

The hereditary behaviour of resistance to scab in pears is in several respects similar to the inheritance of resistance to the attack of the woolly aphis, Eriosoma lanigerum in apples, of. Crane (1937) and Crane et al. (1936).

It may be recalled that in our studies in cultivated apples (Crane and Lawrence, 1933; Lewis and Crane, 194I) discontinuity, even in vegetative characters, was far less frequent than in pears. Moffett (1934) found that secondary association of chromosomes was frequent in apples but rare in pears. Thomas and Revell (1946) have concluded that secondary association results from heterochromatic attraction of 
chromosomes with corresponding segments of heterochromatin; secondary association in this way indicates homology.

It is generally agreed that two or more species have taken part in the origin of the cultivated apple while the origin of the cultivated pear is simpler. These differences between apples and pears doubtless account for the differences both in chromosome behaviour and in mode of variation.

Accounts all agree that the fruits of truly wild pears, Pyrus communis, from which our European cultivated varieties are derived are small, nearly round, hard, gritty, sour, astringent and late ripening. Selection has been towards larger and longer fruits with softer and sweeter flesh and an absence or reduction of grit cells. In some of the characters we have analysed, such as size and length of fruit there has been in the progeny a pronounced shift towards the characters of the wild type. In other characters, such as texture, sweetness and season of ripening no shift in this direction occurs. It is probable that selection for these characters of the fruit has been more rigid than selection for mere shape and size. In addition these characters, which together determine fruit quality, appear to be closely correlated. Sour and astringent pears are usually late ripening and in selecting for a reduction of sourness and astringency, selection has at the same time been towards early ripening.

Early ripening in pears appears to be correlated with a fleeting or insipid flavour since most of the early-ripening individuals we have raised, and also a high proportion of the early-ripening varieties in cultivation, are of this kind. Though not quite so pronounced the same situation is found in apples ; the desirable combination of a degree of sweetness and acidity with the maintenance of flavour for an appreciable time is rare with early ripening in both apples and pears. It seems that the highest qualities of flavour are bound up with a certain degree of acidity and that this is associated with a slower development and hence later ripening.

Selection for desirable fruit characters in pears has been going on for centuries, but it has been much slower since pears are slow to reach maturity and also commonly vegetatively reproduced, than it has been in crops which are annually reproduced by sexual reproduction.

\section{SUMMARY}

Inheritance of the characters of the leaves, growth and fruits of pears have been studied, also of resistance to pear scab Venturia pirina.

In pears, unlike apples, five simple mendelian differences of the leaves and growth were found. These we have used in a classification of cultivated varieties.

This difference between pears and apples is related to differences in secondary chromosome association and in phyletic origin. 
Many quantitative differences, especially in fruit characters, were found to have a polygenic basis.

Resistance to pear scab also has a polygenic basis. In addition there was a reciprocal difference in crosses. The carrier of resistance was less effective on the male side which suggest that the cytoplasm may take part in the inheritance of resistance.

In fruit size and shape seedlings from cultivated varieties preponderate towards wild type.

We are indebted to Mr A. G. Brown and Mr P. Day for assistance in these experiments.

\section{REFERENCES}

CRANE, M. B. 1937 .

Breeding immune rootstocks.

Ann. appl. Biol. 24, 188-195.

CRANE, M. B., AND LAWRENCE, W. J. C. 1933.

Genetical studies in cultivated apples.

7. Genet. 27, 265-296.

CRANE, M. B., GREENSLADE, R. M., MASSEE, A. M., AND TYDEMAN, H. M. 1936.

Studies on the resistance and immunity of apples to the woolly aphis Eriosoma lanigerum (Hausm).

7. Pomol. 14, 137-163.

CRANE, M. B., AND THOMAS, P. T. 1939 .

Genetical studies in pears. I. The origin and behaviour of a new giant form.

7. Genet. 37, 287-299.

CRANE, M. B., AND LEWIS, D. I940.

Genetical studies in pears. II. A classification of cultivated varieties.

7. Pomol. 18, 52-60.

CRANE, M. B., AND LEWIS, D. 1942.

Genetical studies in pears. III. Incompatibility and sterility.

7. Genet. 43, 3 1-43.

KIKUCHI, A. I930.

On the skin colour of the Japanese pear, and its inheritance (in Japanese).

Cont. Inst. Plant Industry Kyoto Imp. Univ. 8, I-50.

LEWIS, D., AND CRANE, M. B. 1938.

Genetical studies in apples II.

7. Genet. 37, 1 $19-128$.

LEWIS, D., AND MODLIBOWSKA, I. 1942.

Genetical studies in pears. IV. Pollen tube growth and incompatibility.

7. Genet. 43, 21 I-222.

MOFFETT, A. A. 1933 .

Cytological studies in cultivated pears.

Genetica, 15, 51 1-518.

THOMAS, P. T., AND REVELL, S. H. 1946.

Secondary association and heterochromatic attraction.

Ann. Bot. N.S. 1o, 159-164.

WELLINGTON, R. I913.

Inheritance of the russet skin in the pear.

Science N.S. 37, 156-157. 